\title{
ADECHLORIN, A NEW ADENOSINE DEAMINASE INHIBITOR CONTAINING CHLORINE PRODUCTION, ISOLATION AND PROPERTIES
}

\author{
Satoshi Ōmura, Nobutaka Imamura, Hiroshi Kuga, Hideyo Ishikawa, \\ Yukiko Yamazaki, Keiko Okano, Keiko Kimura, \\ YōKo TAKAHASHI and HARUO TANAKA
}

The Kitasato Institute and School of Pharmaceutical Sciences, Kitasato University, Minato-ku, Tokyo 108, Japan

(Received for publication April 2, 1985)

\begin{abstract}
Adechlorin exhibiting a potent inhibitory activity against calf intestinal adenosine deaminase was isolated from the cultured broth of Actinomadura sp. OMR-37. The molecular formula was $\mathrm{C}_{11} \mathrm{H}_{15} \mathrm{~N}_{4} \mathrm{O}_{4} \mathrm{Cl}$. The aglycone of adechlorin was identical with that of the known adenosine deaminase inhibitors coformycin and 2'-deoxycoformycin. Adechlorin did not exhibit inhibitory activity against various bacteria and fungi at $1.0 \mathrm{mg} / \mathrm{ml}$. The $K i$ values for adechlorin, coformycin and 2'-deoxycoformycin against adenosine deaminase were determined to be $5.3 \times 10^{-10} \mathrm{M}, 2.1 \times 10^{-10} \mathrm{M}$ and $7.6 \times 10^{-11} \mathrm{M}$, respectively. Adechlorin as well as coformycin and $2^{\prime}$-deoxycoformycin enhanced the antiviral activity of Ara-A. The acute toxicity of adechlorin in mice was less than those of coformycin and $2^{\prime}$-deoxycoformycin.
\end{abstract}

In the course of our screening work for new adenosine deaminase inhibitors from microorganisms, a new adenosine deaminase inhibitor, which was named adechlorin, was isolated from the cultured broth of Actinomadura sp. OMR-37 which was isolated from a soil sample collected at Hodaka-cho, Nagano Prefecture, Japan.

This paper discribes the taxonomy of the producing organism, fermentation, isolation, physicochemical characteristics and biological properties of adechlorin.

Taxonomy of the Producing Strain OMR-37

\section{Morphological Characters}

The vegetative mycelium grows well on both synthetic and complex agar media, and does not show fragmentation into coccoid of bacillary elements. The aerial mycelium is poorly produced and monopodially branched on yeast extract - malt extract agar, oatmeal agar, inorganic salts - starch agar and sucrose - nitrate agar. The short spore-chains (10 20 spores per chain) are flexuous or looped in shape (Plate 1). Pseudosporangia are also formed (Plate 2).

Whole-cell Analysis

Hydrolyzed whole cells contain the meso-diaminopimelic acid and madurose, but no arabinose or xylose. This indicates that the strain is an actinomycete of cell wall type III B according to classification of LeCHEVALIER and LeChevalieR ${ }^{1}$.

Based on the taxonomic properties described above, strain OMR-37 is considered to belong to the genus Actinomadura ${ }^{2)}$. Actinomadura sp. OMR-37 has been deposited in the Fermentation Research Institute, Agency of Industrial Science and Technology, Japan, with an accession number of FERM-P 7987.

The stock culture of strain OMR-37 was inoculated into $100 \mathrm{ml}$ of a seed medium ( $\mathrm{pH} 7.0$ ) con- 
Plate 1. Scanning electron micrograph of aerial mycelia of strain OMR-37 grown on sucrosenitrate agar.

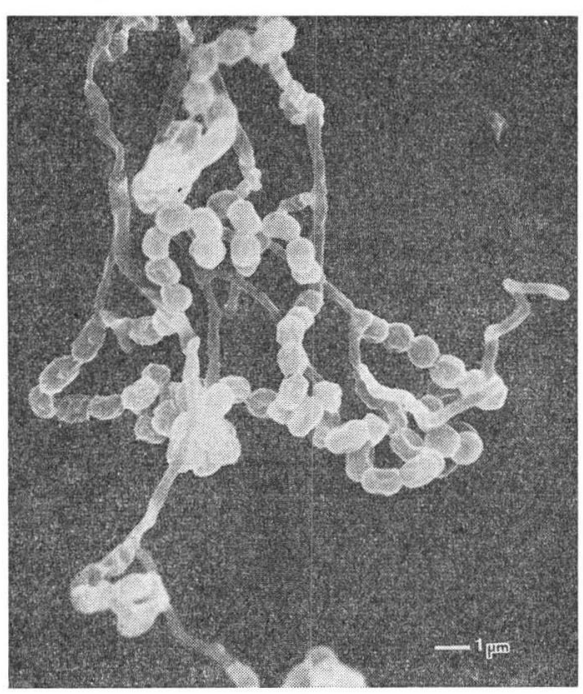

Plate 2. Scanning electron micrograph of pseudosporangium of strain OMR-37 grown on sucrose nitrate agar.

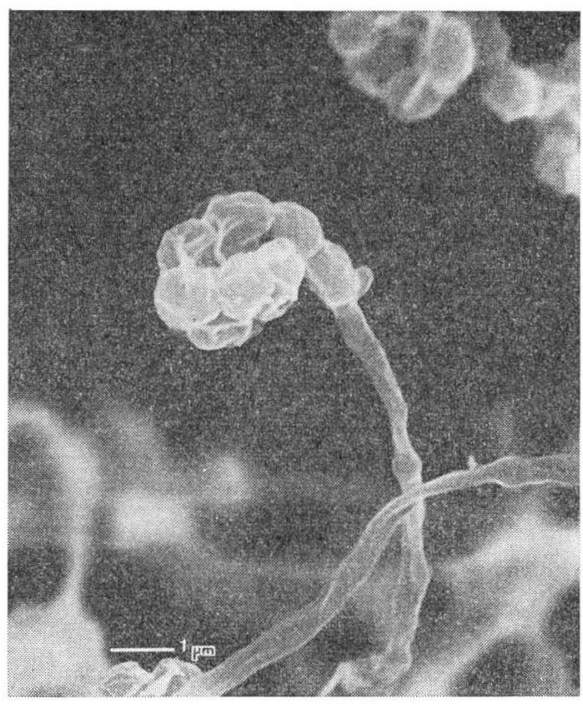

sisting of glucose $0.1 \%$, potato starch $2.4 \%$, Bacto-tryptone $0.5 \%$, meat extract $0.3 \%$, yeast extract $0.5 \%$ and $\mathrm{CaCO}_{3} 0.2 \%$ in a $500-\mathrm{ml}$ Erlenmeyer flask and incubated at $30^{\circ} \mathrm{C}$ for 4 days. One liter of the seed culture was transferred to 20 liters of a production medium ( $\mathrm{pH} 7.0$ ) containing glucose $0.1 \%$, soluble starch $2.4 \%$, meat extract $0.3 \%$, Bacto-tryptone $0.5 \%$, yeast extract $0.5 \%$ and $\mathrm{CaCO}_{3} 0.2 \%$ in a 30-liter jar fermentor and the aerobic fermentation was carried out at $30^{\circ} \mathrm{C}$. Adechlorin concentration was monitored with adenosine deaminase inhibiting activity assayed by the modified method of MeIER and CONSCIENCE ${ }^{3)}$, and with HPLC (ODS column, 0.1 M AcONa buffer (pH 5.75) - 5\% acetonitrile, retention time 21.4 minutes). In the modified assay system, the enzyme reaction mixture was developed on cellulose TLC with $5 \% \mathrm{Na}_{2} \mathrm{HPO}_{4}$ saturated with isoamyl alcohol and then detected by a UV scanner. The adenosine deaminase inhibiting activity of the cultured broth occurred at 26 hours after the inoculation, then gradually increased and reached maximum at 42 hours. The cultured broth (40 liters) was centrifuged to obtain about 38 liters of a supernatant fluid, which applied to a column of activated carbon (2.5 liters). After the column being washed with water, the active material was eluted with $15 \%$ and $50 \%$ aqueous $\mathrm{Me}_{2} \mathrm{CO}$. The active eluate was concentrated in vacuo and lyophilized to give a brown powder $(67.4 \mathrm{~g})$. The powder was dissolved in small volume of $\mathrm{H}_{2} \mathrm{O}$ and then poured into EtOH. After the removal of the flocculated material by filtration, the filtrate was evaporated to dryness. The resulting brown paste $(9.8 \mathrm{~g})$ was chromatographed on a Diaion HP-20 column $(500 \mathrm{ml})$ with $10 \%$ aqueous MeOH. The active fractions were combined, concentrated under the reduced pressure and lyophilized to yield a crude powder (5.5 g). The powder was charged to a column of silica gel $(150 \mathrm{~g})$ and developed with $\mathrm{BuOH}$ containing $\mathrm{H}_{2} \mathrm{O}$. The active eluate was evaporated to dryness. The residue $(1.0 \mathrm{~g})$ was purified on a Toyopearl HW-40 (500 ml) column with EtOH $-\mathrm{H}_{2} \mathrm{O}(1: 9)$. The active fractions containing adechlorin and the other inhibitor, were combined separately and then freeze-dried to give a white powder (92 mg) and a yellow paste (320 mg), respectively. Further purification was carried out by using a preparative HPLC column of reversed phase silica gel (ODS) with $5 \%$ aqueous acetonitrile as developing solvent to provide a pure 
form adechlorin as an amorphous white powder $(57 \mathrm{mg})$. Adechlorin was recrystallized from $\mathrm{H}_{2} \mathrm{O}$ to give $9 \mathrm{mg}$ as colorless needles. The above yellow paste was also chromatographed by the same method to yield a white powder $\left(70 \mathrm{mg}\right.$ ), which was identified with $2^{\prime}$-deoxycoformycin by ${ }^{1} \mathrm{H}$ NMR analysis ${ }^{4)}$.

\section{Physico-chemical Properties}

Adechlorin is readily soluble in $\mathrm{H}_{2} \mathrm{O}, \mathrm{MeOH}$ and $\mathrm{EtOH}$ and slightly soluble in aqueous $\mathrm{Me}_{2} \mathrm{CO}$ but practically insoluble in EtOAc, $\mathrm{CHCl}_{3}$ and $n$-hexane. It gave positive reactions with anisaldehyde$\mathrm{H}_{2} \mathrm{SO}_{4}$ and $\mathrm{KMnO}_{4}$, but negative to ninhydrin. Adechlorin was recrystallized from $\mathrm{H}_{2} \mathrm{O}$ as colorless needles, mp $125 \sim 131^{\circ} \mathrm{C},[\alpha]_{\mathrm{D}}^{20}+21^{\circ}\left(c 1.0, \mathrm{H}_{2} \mathrm{O}\right) . \quad$ The UV $\left[\lambda_{\max }^{\mathrm{H}_{\mathrm{O}} \mathrm{O}} \mathrm{nm}(\varepsilon) ; 283(12,080)\right]$ and IR (Fig. 1)

Fig. 1. The IR spectrum (KBr) of adechlorin.

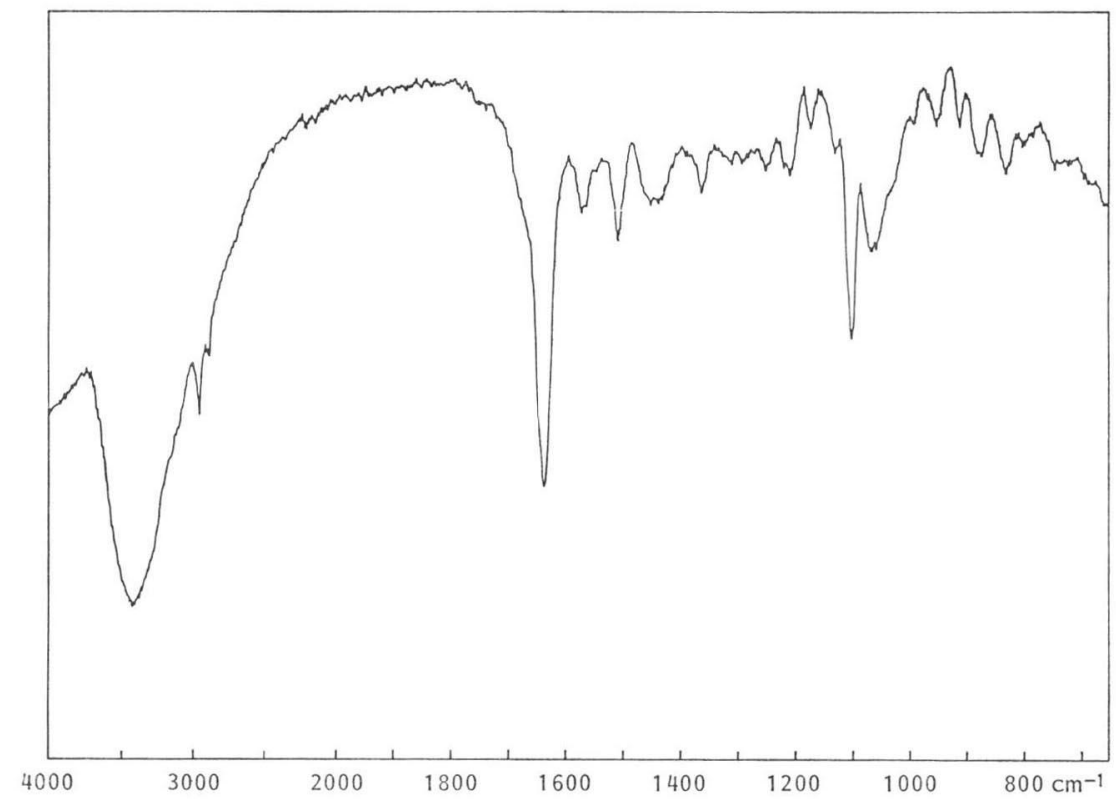

Fig. 2. The ${ }^{1} \mathrm{H}$ NMR spectrum $\left(90 \mathrm{MHz}\right.$, in $\left.\mathrm{D}_{2} \mathrm{O}\right)$ of adechlorin.

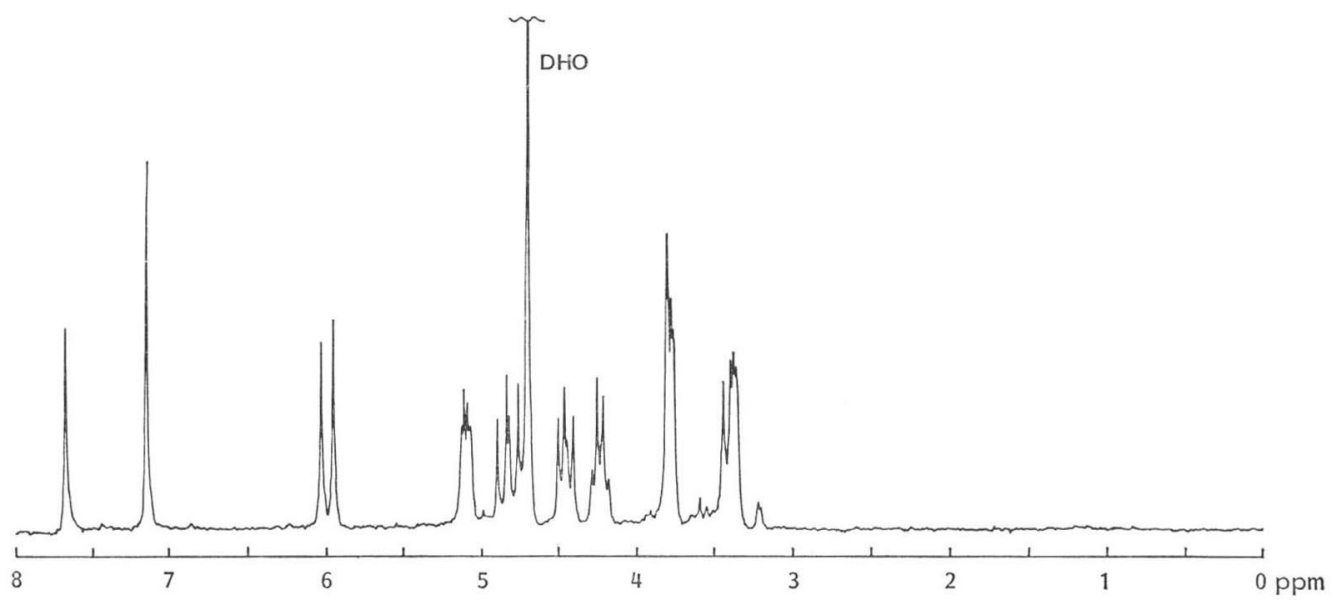


Fig. 3. The ${ }^{13} \mathrm{C}$ NMR spectrum $\left(22.5 \mathrm{MHz}\right.$, in $\left.\mathrm{D}_{2} \mathrm{O}\right)$ of adechlorin.

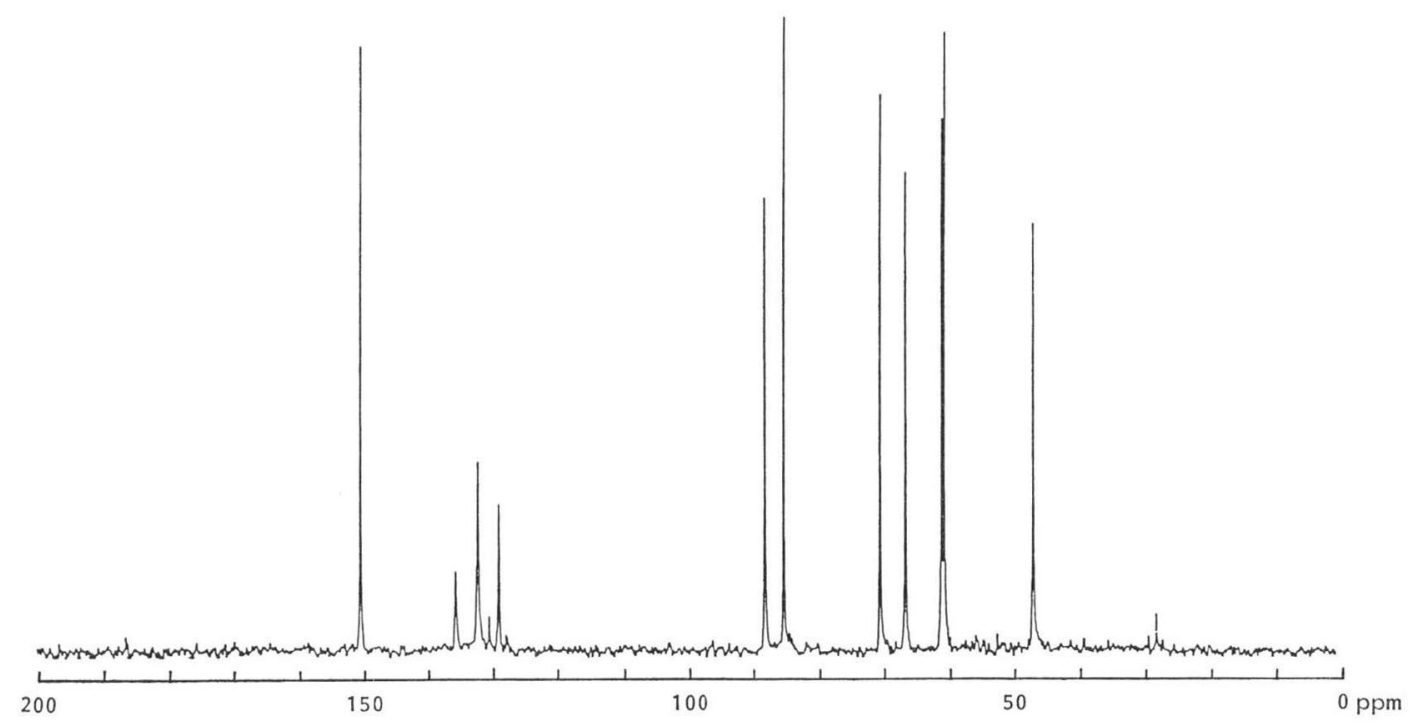

spectra of adechlorin closely resembled those of coformycin ${ }^{5)}$ and 2 -deoxycoformycin ${ }^{6)}$. The molecular formula of adechlorin was established to be $\mathrm{C}_{11} \mathrm{H}_{15} \mathrm{~N}_{4} \mathrm{O}_{4} \mathrm{Cl}$, since the result of the high-resolution mass spectrum of the tetraacetate indicated its formula to be $\mathrm{C}_{18} \mathrm{H}_{23} \mathrm{~N}_{4} \mathrm{O}_{8} \mathrm{Cl}$ [calcd $472.118(\mathrm{M}+2)^{+}$, $470.120(\mathrm{M})^{+}$, found $\left.472.118(\mathrm{M}+2)^{+}, 470.116(\mathrm{M})^{+}\right]$. It was also supported by the EI mass spectrum $\left[\mathrm{m} / \mathrm{z} 304(\mathrm{M}+2)^{+}, 302(\mathrm{M})^{+}\right]$and the elementary analysis [calcd for $\mathrm{C}_{11} \mathrm{H}_{15} \mathrm{~N}_{4} \mathrm{O}_{4} \mathrm{Cl}, \mathrm{C} 43.64 \%$, $\mathrm{H} 4.99, \mathrm{~N} 18.51, \mathrm{Cl} 11.71$, found $\mathrm{C} 43.24 \%, \mathrm{H} 5.01, \mathrm{~N} \mathrm{17.42,} \mathrm{Cl} \mathrm{10.75]} \mathrm{of} \mathrm{adechlorin.} \mathrm{The}{ }^{1} \mathrm{H} \mathrm{NMR}$ spectrum of adechlorin (Fig. 2) suggested the existence of the same aglycone with coformycin ${ }^{7)}$ and 2'-deoxycoformycin ${ }^{6)}$, which have 3,6,7,8-tetrahydroimidazo[4,5-d][1,3]diazepin-8-ol, i.e., 3.30 (m, $2 \mathrm{H}), 5.05(\mathrm{dd}, 1 \mathrm{H}), 7.20(\mathrm{~s}, 1 \mathrm{H}), 7.65(\mathrm{~s}, 1 \mathrm{H}) \mathrm{ppm}$. The signal assignable as an anomeric proton [6.00 (d) ppm] suggested the presence of a sugar. The ${ }^{13} \mathrm{C}$ NMR spectrum (Fig. 3) also indicated the presence of the above-mentioned chromophore [47.6 (t), 67.2 (d), 129.3 (s), 132.5 (d), 135.8 (s), 150.6 (d) ppm] $]^{\text {s) }}$ and the sugar moiety [61.3 (d), 61.7 (t), 71.1 (d), 85.8 (d), 88.6 (d) ppm]. Therefore, adechlorin is considered to consist of the same aglycone with coformycin and 2'-deoxycoformycin and a pentose containing a chlorine atom.

Kinetics of the Inhibition of Adenosine Deaminase by Adechlorin

Adenosine deaminase inhibiting activity was assayed by the spectrophotometric tracing of the reaction mixture as described by AgARwal et al..$^{8)}$. Kinetics was also examined as described by them. They classified adenosine deaminase inhibitors into three types of readily reversible, semitight-binding and tight-binding inhibitors. Adechlorin exhibited complete inhibition against adenosine deaminase at the concentration of $100 \mathrm{~nm}$ without preincubation. As shown in Fig. 4, the inhibition was not almost observed at the concentration of $1.0 \mathrm{~nm}$ adechlorin without preincubation. On the contrary, when $1.0 \mathrm{~nm}$ adechlorin was preincubated in the reaction mixture for 15 minutes, it exhibited potent inhibitory activity and the inhibition continued for a long time. This indicated that adechlorin is an inhibitor of tight-binding type like coformycin and $2^{\prime}$-deoxycoformycin ${ }^{8,8)}$. 
Fig. 4. The effect of preincubation on the inhibition of calf intestinal adenosine deaminase (EC 3.5.4.4 Type III; Sigma Chem. Co.) by adechlorin.

(-) Non-preincubation, (+) preincubated for 15 minutes.

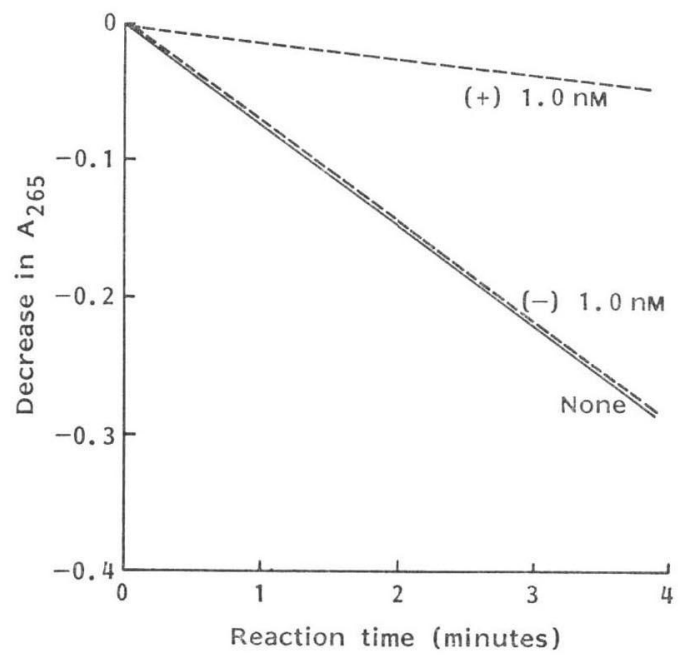

The $K i$ value of adechlorin was assayed according to the method of CHA et al. ${ }^{\left.{ }^{9}\right)}$. The $\mathbf{I}_{50}$ values at varied enzyme concentrations were determined from the results of Fig. 5A, and then those were plotted against the concentration of enzymes as shown in Fig. 5B. The $K i$ value of adechlorin was determined to be $5.3 \times 10^{-10} \mathrm{M}$, and those of coformycin and 2'-deoxycoformycin were $2.1 \times 10^{-10}$ and $7.6 \times 10^{-11} \mathrm{M}$, respectively.

\section{Biological Properties}

The adenosine deaminase inhibitor adechlorin did not exhibit antimicrobial activity against various bacteria and fungi at the concentration of $1.0 \mathrm{mg} / \mathrm{ml}$. It enhanced the antiviral activity of Ara-A as described below. The acute toxicity of adechlorin was preliminarily examined compared with coformycin and 2'-deoxycoformycin. When adechlorin was administered intravenously

Fig. 5.

A; Determination of $I_{50}$ values of adechlorin for various enzyme concentrations.

Various amounts of adenosine deaminase were incubated in a mixture (total volume, $1.8 \mathrm{ml}$ ) containing $50 \mathrm{~mm}$ potassium phosphate buffer and varying concentrations of adechlorin. After preincubation for 15 minutes, the enzyme reaction was started by the addition of $200 \mu \mathrm{l}$ of $2.0 \mathrm{~mm}$ of adenosine. The reaction was followed by measuring the decrease in absorbance at $265 \mathrm{~nm}$.

Adenosine deaminase (unit/ml): $\bigcirc 0.05,0.10, \square 0.15$, 罝 0.20 .

B; Determination of $K i$ value of adechlorin.

$\mathbf{I}_{50}$ values estimated from $\mathrm{A}$ and are plotted against enzyme concentration. The crossed point with $\mathrm{I}_{50}$ axis is the $K i$ value of adechlorin $\left(K i=5.3 \times 10^{-10} \mathrm{M}\right)$.

A

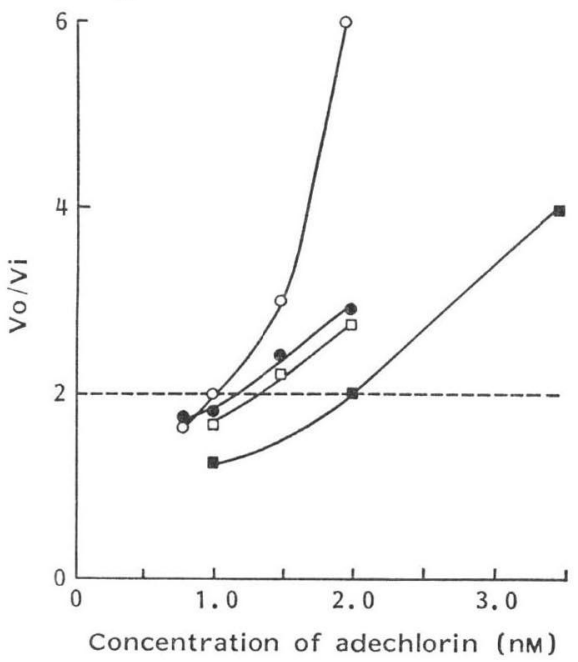

B

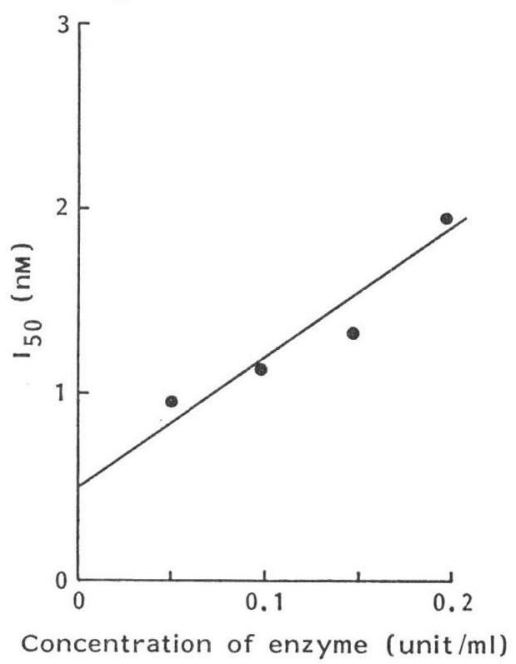


to mice at the dose of $100 \mathrm{mg} / \mathrm{kg}$; the acute toxicity was not observed although some weight loss was observed. The $\mathrm{LD}_{50}$ (in mice, iv) of coformycin and $2^{\prime}$-deoxycoformycin were found to be $<25$ and $>100 \mathrm{mg} / \mathrm{kg}$, respectively, the latter exhibited significant weight loss of mice at the doses over $25 \mathrm{mg} / \mathrm{kg}$. As a result, the acute toxicity of adechlorin seems to be the lowest among these adenosine deaminase inhibitors.

\section{Effect of Adechlorin on the Antiviral Activity of Ara-A}

Because coformycin and 2'-deoxycoformycin are known to potentiate the antiviral activity of Ara$\mathrm{A}^{10,11)}$, the enhancing effect of adechlorin on the antiviral activity of Ara-A was examined. Antiviral activity was assayed by plaque reduction method ${ }^{12)}$ using HeLa S3 cells infected with herpes simplex virus type I (HSV-I). Subconfluent HeLa S3 cells $\left(3 \times 10^{8}\right.$ per $35 \mathrm{~mm}$ Petri dish) were infected with HSV-I at 50 pfu per dish in $0.1 \mathrm{ml}$ of a medium containing horse serum. After the adsorption for 2 hours at $37^{\circ} \mathrm{C}, 2 \mathrm{ml}$ of medium consisting of $2.0 \%$ horse serum, $1.0 \%$ agar and various concentrations of Ara-A with or without $2.5 \mu \mathrm{M}$ adenosine deaminase inhibitor was added into the dish, and then the dishes were incubated for 2 days at $37^{\circ} \mathrm{C}$ in a $\mathrm{CO}_{2}$ incubator. One milliliter of calcium/magnesiumfree phosphate-buffered saline including $0.02 \%$ neutral red and $1.0 \%$ agar was overlaid. After the incubation for $6 \sim 7$ hours under the above conditions, the number of plaque was counted. The enhancing effects of adechlorin, coformycin and $2^{\prime}$-deoxycoformycin were shown in Fig. 6 . The effect of adechlorin was equivalent to those of coformycin and 2'-deoxycoformycin.

From the above data, it was found that adechlorin is a new potent adenosine deaminase inhibitor constructed with 3,6,7,8-tetrahydroimidazo[4,5-d][1,3]diazepin-8-ol and a sugar containing a chlorine atom. The natural occurrence of the sugar moiety including a chlorine atom is the first finding.

Fig. 6. Effects of adenosine deaminase inhibitors on HSV-1 replication in a monolayer culture of HeLa $\mathrm{S} 3$ cells.

- Ara-A $\left(\mathrm{ED}_{50}=14 \mu \mathrm{M}\right), \bigcirc$ Ara-A + adechlorin $(2.5 \mu \mathrm{M}), \mathbf{A}$ Ara-A + coformycin $(2.5 \mu \mathrm{M}), \square$ Ara$\mathrm{A}+2^{\prime}$-deoxycoformycin $(2.5 \mu \mathrm{M})$.

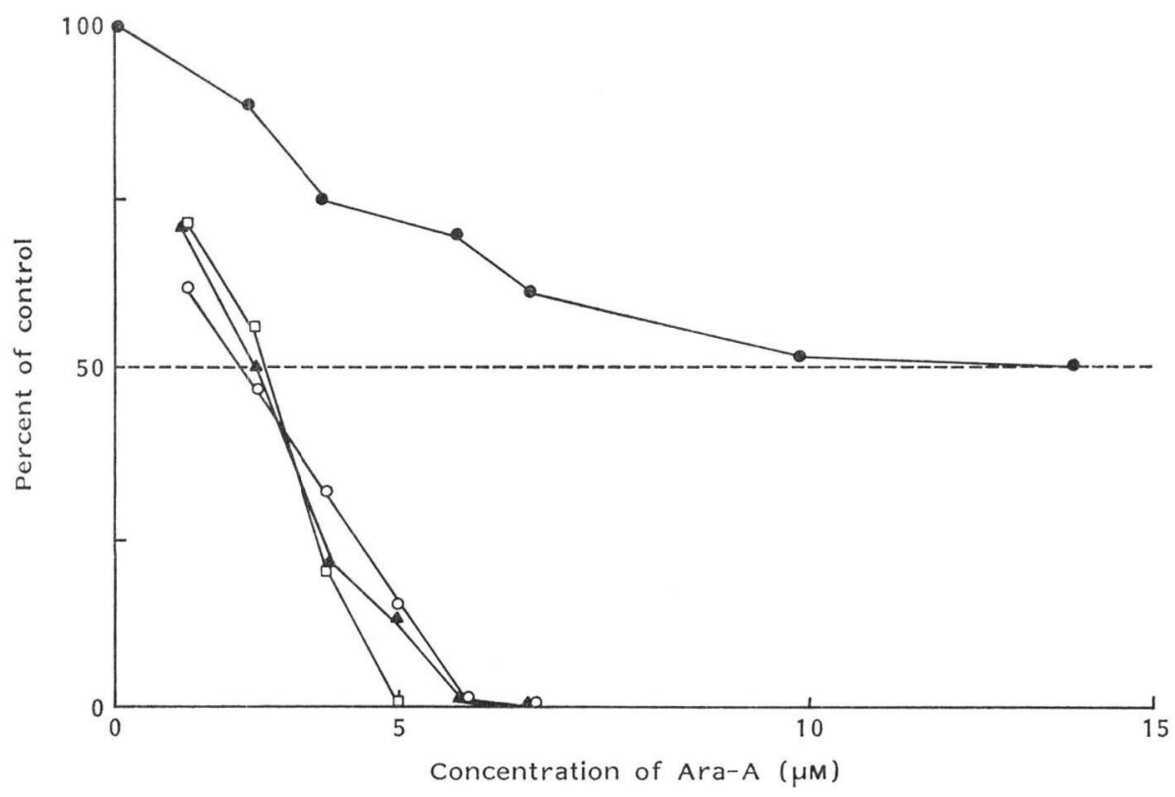


Fig. 7. The proposed structure of adechlorin.

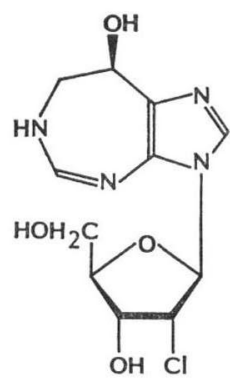

HANVEY et al. ${ }^{13)}$ reported that 2'-deoxycoformycin is derived from an intact adenosine molecule and a $\mathrm{C}_{1}$ unit. Since the producer of adechlorin co-produced 2'-deoxycoformycin, the biosynthesis of adechlorin would be similar to that of 2'-deoxycoformycin and the stereochemistry would be the same except at C-2'. Thus, the stereochemistry of the sugar moiety of adechlorin should be either D-ribose or Darabinose type.

The ${ }^{1} \mathrm{H}$ NMR coupling constants $\left(J_{1,2}=7.3\right.$ and $\left.J_{2,3}=3.3 \mathrm{~Hz}\right)$ of triacetyl pentopyranose, which obtained by acidic hydrolysis and then treatment with acetic anhydride and pyridine, suggested $\beta$-Dribose type. The structure of adechlorin including the streochemistry seems to be as shown in Fig. 7 . The structure determination is in progress and the details will be published in the near future.

\section{Acknowledgments}

We would like to acknowledge Mr. R. Masuma, Dr. H. Ikeda and Dr. K. Kомiyama for large scale production, some, useful advices, and toxicity experiments, respectively. This work was partially supported by a grant from Japan Keirin Association.

\section{References}

1) Lechevalier, M. P. \& H. A. Lechevalier: Chemical composition as a criterion in the classification of aerobic actinomycetes. Int. J. Syst. Bacteriol. 20: 435 443, 1970

2) Lechevalier, H. A. \& M. P. Lechevalier: A critical evaluation of the genera of aerobic actinomycetes. In The Actinomycetales. Ed., H. Prouser, pp. $393 \sim 405$, Gustav Fischer Verlag, Jena, 1970

3) Meier, W. \& J.-F. Conscience: A fast and simple radiometric assay for adenosine deaminase using reversed-phase thin-layer chromatography. Anal. Biochem. 105: 334 339, 1980

4) Woo, P. W. K.; H. W. Dion, S. M. Lange, L. F. Dahl \& L. J. Durham: A novel adenosine and Ara-A deaminase inhibitor, (R)-3-(2-deoxy- $\beta$-D-erythro-pentofuranosyl)-3,6,7,8-tetrahydroimidazo[4,5- $d][1,3]$ diazepin-8-ol. J. Heterocycl. Chem. 11: 641 643, 1974

5) Takeuchi, T.; N. Ezaki, S. Amano, C. Uchida \& T. NiIda: Studies on coformycin. I. Isolation and characterization of coformycin. Sci. Rep. Meiji Seika Kaisha 11: 17 21, 1970

6) Dion, H. W.; P. W. K. Woo \& A. Ryder: Isolation and properties of a vidarabine deaminase inhibitor, co-vidarabine. Ann. N.Y. Acad. Sci. 284: 21 29, 1978

7) Nakamura, H.; G. Koyama, Y. Iitaka, M. Ohno, N. Yagisawa, S. Kondo, K. Maeda \& H. Umezawa: Structure of coformycin, an unusual nucleoside of microbial origin. J. Am. Chem. Soc. 96: 4327 4328, 1974

8) Agarwal, R. P.; T. Spector \& R. E. Parks, Jr.: Tight-binding inhibitors-IV. Inhibition of adenosine deaminase by various inhibitors. Biochem. Pharmacol. 26: 359 367, 1977

9) Cha, S.; R. P. Agarwal \& R. E. Parks, Jr.: Tight-binding inhibitors-II. Non-steady state nature of inhibition of milk xanthine oxidase by allopurinol and alloxanthine and of human erythrocytic adenosine deaminase by coformycin. Biochem. Pharmacol. 24: 2187 2197, 1975

10) Schwartz, P. M.; C. Shipman, Jr. \& J. C. Drach: Antiviral activity of arabinosyladenine and arabinosylhypoxanthine in herpes simplex virus-infected $\mathrm{KB}$ cells. Selective inhibition of viral deoxyribonucleic acid synthesis in the presence of an adenosine deaminase inhibitor. Antimicrob. Agents Chemother. 10: $64 \sim 74,1976$

11) Agarwal, R. P.; J. Blatt, J. Miser, S. Sallan, J. M. Lipton, G. H. Reaman, J. Holcenberg \& D. G. PoplaCK: Clinical pharmacology of 9- $\beta$-D-arabinosyladenine in combination with 2 -deoxycoformycin. Cancer Res. 42: $3884 \sim 3886,1982$ 
12) Connor, J. D.; L. Sweetman, S. Carey, M. A. Stuckey \& R. Buchaman: Effect of adenosine deaminase upon the antiviral activity in vitro of adenine arabinide for vaccinia virus. Antimicrob. Agents Chemother. 6: 630 636, 1974

13) Hanvey, J. C.; J. K. Hardman, R. J. Suhadolnik \& D. C. Baker: Evidence for the conversion of adenosine to $2^{\prime}$-deoxycoformycin by Streptomyces antibioticus. Biochemistry 23: 904 907, 1984 